OPEN ACCESS

Edited by:

Prannoy Suraneni,

University of Miami, United States

Reviewed by:

Jianyun Wang,

Xi'an Jiaotong University, China

Assed Haddad,

Federal University of Rio de Janeiro,

Brazil

*Correspondence: Emanuele Rossi

e.rossi@tudelft.n

${ }^{\dagger}$ These authors have contributed equally to this work

Specialty section:

This article was submitted to

Sustainable Design and Construction,

a section of the journal

Frontiers in Built Environment

Received: 24 November 2020 Accepted: 04 January 2021

Published: 28 January 2021

Citation:

Rossi E, Vermeer CM, Mors $R$, Kleerebezem $R$, Copuroglu $O$ and Jonkers HM (2021) On the Applicability of a Precursor Derived from Organic

Waste Streams for Bacteria-Based

Self-Healing Concrete.

Front. Built Environ. 7:632921.

doi: 10.3389/fbuil.2021.632921

\section{On the Applicability of a Precursor Derived from Organic Waste Streams for Bacteria-Based Self-Healing Concrete}

\author{
Emanuele Rossi ${ }^{1 * t}$, Chris M. Vermeer ${ }^{2 \dagger}$, Renee Mors ${ }^{1,3}$, Robbert Kleerebezem ${ }^{2}$, \\ Oguzhan Copuroglu ${ }^{1}$ and Henk M. Jonkers ${ }^{1}$
}

${ }^{1}$ Department of Materials and Environment, Faculty of Civil Engineering and Geosciences, Delft University of Technology, Delft, Netherlands, ${ }^{2}$ Department of Biotechnology, Delft University of Technology, Delft, Netherlands, ${ }^{3}$ Green-Basilisk B.V., Delft, Netherlands

Bacteria-based self-healing concrete has the ability to heal cracks due to the bacterial conversion of incorporated organic compounds into calcium carbonate. Precipitates seal the cracks, theoretically increasing the service life of constructions. The aim of this paper is to propose a precursor for bacteria-based self-healing concrete derived from organic waste streams, produced is in line with the circular economy principle and ideally more affordable than other substrates. To verify the applicability of the proposed healing agent, some fundamental requirements of the proposed system are studied, such as its influence on functional properties, crack sealing capacity and evidence of bacterial activity in concrete.

Keywords: bacteria, self-healing, durability, crack sealing, concrete, sustainability

\section{INTRODUCTION}

To improve the durability of construction materials, self-healing concrete gathered high attention from both industry and scientific community during the last decades. Due to the relatively low tensile strength of concrete, cracks are an unavoidable phenomena affecting concrete structures during their service life. However, concrete has an intrinsic autogenous ability to heal cracks (de Rooij et al., 2013). Autogenous healing occurs through continuous hydration of cement particles and through precipitation of calcium carbonate resulting from carbonation of the matrix (Hearn, 1998). Nevertheless, autogenous healing has a healing capacity limited to cracks $0.1-0.2 \mathrm{~mm}$ wide (Edvardsen 1999; Li and Yang, 2007; De Belie et al., 2018). Self-healing capacity of concrete can be improved thanks to several methods (De Belie et al., 2018): among others, biogenic concrete has proved to be a promising solution to improve water tightness and potentially the service-life of constructions (Jonkers et al., 2010).

In biogenic concrete, bacteria and a mineral precursor compound are added into the mix before casting. When cracks occur in hardened concrete, the healing system is activated by the ingress of water and sustained by the availability of oxygen. Bacterial metabolic activity converts the organic compound into calcium carbonate, which precipitation enables to heal the cracks. Cracks closure reduce the ingress of water and harmful agents (i.e., chlorides) and, therefore, it is expected to improve the durability of concrete. Several methodologies have been proposed in the current literature to improve the self-healing capacity of concrete, such as incorporating fibers (Li et al., 1998; Yang et al., 2009), superabsorbent polymers (Kim and Schlangen, 2011; Snoeck 
et al., 2016) and encapsulated healing agents (Van Tittelboom et al., 2011; Wiktor and Jonkers, 2011; Wang et al., 2014a; Wang et al., 2014b; Mors and Jonkers, 2017a; Mors and Jonkers, 2017b; Palin et al., 2017; Wang et al., 2018; Pungrasmi et al., 2019; Xu et al., 2019). One of the first studies on the applicability of the latter technology was conducted by Mors and Jonkers (Mors and Jonkers 2017a; Mors and Jonkers 2017b) who studied the effect of calcium lactate derivate as microencapsulated healing precursor during the last decade. The capsules had a size of 1-3 mm and were added in (CEM SBN 175 III/4) mortar mixture as of $4 \%$ by weight of cement. As a result, the maximum crack width that their system could heal after 100 days of incubation (i.e., $20^{\circ} \mathrm{C}$, $\mathrm{RH}>95 \%$ and water submersion) was $650 \mu \mathrm{m}$. Pungrasmi et al. 2019 investigated the effects of $2 \% \mathrm{w} / \mathrm{w}$ of capsules composed of sodium alginate and bacterial spores (Bacillus sphaericus LGMG 22257) added in Portland cement (CEM I) mortar. After 7 days of healing incubation (i.e., wet/dry cycles of water), their system demonstrated a SHC equal to $95 \%$ for cracks $200-300 \mu \mathrm{m}$ wide, while their control plain mortar mixture had 73\%. Palin et al. (Palin et al., 2017) proposed a HA that could trigger self-healing in mortar exposed to saline environment. Their study implied the addition in blast furnace slag cement (CEM III/B $42.5 \mathrm{~N} \mathrm{LH}$ ) mortar of $10 \% \mathrm{w} / \mathrm{w}$ of healing agents, which was composed of mineral precursor, nutrients and bacterial spores (Bacillus halmapalus). After 56 days of incubation (i.e., submersion in simulated seawater), the SHC of their proposed system was equal to 95 and $93 \%$ for specimens with a crack width of 400 and $600 \mu \mathrm{m}$, respectively, while the SHC of their control plain mortar mixture was of 66 and $68 \%$, respectively. Wang and others (References) did extensive work on assessing the SHC of mortar with different healing agents. In one of their studies (Wang et al., 2014a) they evaluated the effect of a HA composed of melamine-based microcapsules and spores (Bacillus sphaericus LMG 22557) in Portland cement (CEM I $52.5 \mathrm{~N}$ ) mortar. The proposed HA was in form of an emulsion and a maximum of around $17.8 \% \mathrm{w} / \mathrm{w}$ was (comprehensive of nutrients, emulsion and microcapsules) was added in the mortar during mixing. The specimens were kept under different incubation conditions for 56 days. Among other incubation conditions, it is remarkable that the SHC of their system had a maximum healed crack width of $850-970 \mu \mathrm{m}$ for specimens exposed to water submersion and of $560-600 \mu \mathrm{m}$ for specimens exposed to wet/dry water cycles. Under the same conditions, their control plain mortar specimens had a maximum healed crack width of 240-250 and $75 \mu \mathrm{m}$, respectively. Furthermore, the SHC of mortar with added-in bacteria and bio-reagents (i.e., yeast extract, urea and calcium nitrate) encapsulated in hydrogels was widely investigated (Wang et al., 2014b; Wang et al., 2018). In Wang et al. $2014 \mathrm{~b}$ a maximum of around $18 \% \mathrm{w} / \mathrm{w}$ of $\mathrm{HA}$ components was added in Portland cement (CEM I 52.5N) mortar specimens. After 28 days of incubation (i.e., wet/dry water cycles), the SHC of their control plain mortar mixture was $15 \pm 10 \%$ while that of the self-healing mortar was around $68 \%$, with a maximum healed crack width of $500 \mu \mathrm{m}$. In (Wang et al., 2018), the application of a chitosan-based hydrogel as self-healing precursor in mortar was investigated. According their water permeability tests, mortar with a maximum of added-in $15 \%$ w/w of HA components had a SHC equal to $87 \pm$ $5 \%$ while their control plain mortar specimens had $59 \pm 10 \%$ after 70 days of incubation (i.e., water submersion). Other specimens were exposed to 70 days of wet/dry water cycles, and they could self-heal cracks up to $255 \mu \mathrm{m}$ wide, while the maximum width that the control specimens could self-heal was $140 \mu \mathrm{m}$. Xu et al. 2019 investigated the applicability of rubber particles as bacteria (Sporosarcina pasteurii ATCC11859) carrier in self-healing concrete. Differently from previous studies, they also investigated the influence that two HA particle sizes have on the properties of the proposed system. The particles ranged between $0.2-0.4 \mathrm{~mm}$ (named as series S) and of 1-3 mm (named as series L). Upon the addition of $14 \% \mathrm{w} / \mathrm{w}$ of HA components in Portland cement (CEM I PO 42.5) concrete specimens, the maximum healed crack width for the L-series specimens was $860 \mu \mathrm{m}$, that of the S-series was $520 \mu \mathrm{m}$ and that of the control plain mortar specimens was $300 \mu \mathrm{m}$ after 28 days of incubation (i.e., water submersion). The regain of compressive strength in was also investigated: as a result, the regain of the L-series was $96 \%$, that of the S-series was $90 \%$ and that of the control series was $85 \%$. A summary of the results related to the above-reported literature survey is visible in Table $\mathbf{1}$.

Even though many encapsulation self-healing engineered solutions have been proposed and studied in the current literature, the application of these technologies is still relatively limited. This fact might be related to many interrelated parameters. Among others, it is visible from Table 1 that some of the proposed technologies require relatively high dosage of healing agents by mass of cement (up to around $18 \%$ ), with consequent increase of materials costs and potential limitations imposed by local regulations. The raw materials from which the healing agents are obtained as well as the particle formulation processes are likely detrimental factors for their final costs, hence making healing agents out of renewable sources might be an economic and environmental advantage. Furthermore, the compatibility between some healing agents and concrete has been mainly tested and demonstrated for mixtures containing Portland cement, while in some cases limited compatibility with low alkaline cementitious environments (i.e., CEM III/B, as typically used in the Netherlands) was reported (Mors and Jonkers, 2017b). To potentially overcome these limitations, alkanoates-derivates extracted from wastewater is proposed as self-healing agent in concrete. Most alkanoates are biodegradable amd they can be derived from organic waste streams (Lee, 1996). The extraction of alkanoates is therefore in line with the circular economy principle and it is ideally more economically advantageous than that of other precursors used in self-healing concrete. Alkanoates can serve as energy source for bacterial metabolic activity, and they do not require alkaline activation to be metabolized by bacteria. Therefore, the self-healing capacity of alkanoate-based concrete could be theoretically extended also to low alkaline mixes (i.e., with low 
TABLE 1 | Overview of performance from previous studies conducted on bacteria-based self-healing concrete with encapsulated healing agents.

\begin{tabular}{|c|c|c|c|c|c|}
\hline References & Healing agent & $\begin{array}{c}\text { Content }^{a} \\
\text { (w/w } \text { wement }_{\text {cem }}\end{array}$ & Cement type & Self-healing days & $\begin{array}{l}\text { Maximum healed } \\
\text { crack width } \\
(\mu \mathrm{m})\end{array}$ \\
\hline Mors and Jonkers (2017a) & CaL derivate capsules & 4.0 & CEM SBN 175 III/4 & 100 & 650 \\
\hline Pungrasmi et al. (2019) & Sodium alginate capsules & 2 & CEM I & 7 & N.A. \\
\hline Palin et al. (2017) & Beads of mineral precursor compounds and bacteria & $\sim 10$ & CEM III/B 42.5 N LH & 56 & $\sim 600$ \\
\hline Wang et al. (2018) & pH-responsive hydrogel & $\sim 14$ & CEM I $52.5 \mathrm{~N}$ & 70 & 255 \\
\hline Wang et al. (2014a) & Melamine-based microcapsules & $\sim 18$ & CEM I $52.5 \mathrm{~N}$ & 56 & $850-970$ \\
\hline Wang et al. (2014b) & Hydrogel with encapsulated bacteria and bio-reagents & $\sim 18$ & CEM I 52.5N & 28 & 500 \\
\hline Xu et al. (2019) & Spore-containing rubber particles & $\sim 14$ & CEM I PO 42.5 & 28 & 860 \\
\hline
\end{tabular}

${ }^{a}$ Representative of the total amount of self-healing components that are added in the mixture compared to each control plain mixture.

TABLE 2 | Composition of healing agents after particle formulation.

\begin{tabular}{lc} 
Ingredients & Mass (\%) \\
\hline Substrate (PLA or alkanoates) & 97.6 \\
Yeast extract & 2 \\
Bacterial spores & 0.4
\end{tabular}

clinker content). Based on the characteristics mentioned above, alkanoates seem ideal candidates to be used in selfhealing bacteria-based concrete, of which characterization is the aim of this study. To do so, three main requirements needed to ensure the performance of self-healing bioconcrete proposed by Tziviloglou et al. 2016a were evaluated. These requirements include the occurrence of mineral formation inside the crack, the re-gain of water tightness in cracked specimens and the evidence of bacterial activity in the matrix. In this study, self-healing capacity of cracked specimens was tested through water permeability test. Mineral formation at the crack mouth as well as inside the crack was investigated through Optical Microscope analysis of the surface cracks and Environmental Scanning Electron Microscopy (ESEM) analysis of the healed specimens. Evidence of bacterial presence and activity in concrete was studied through ESEM analysis for precipitates characterization as well as oxygen consumption measurements in a concrete-like environment. Furthermore, the influence that the proposed alkanoates-based healing agent has on some fundamental functional properties of mortar (i.e., hydration of cement, compression strength and setting time) has been tested to evaluate the feasibility of the proposed technology.

\section{MATERIALS AND METHODS}

\section{Healing Agents}

Alkanoate-derived healing agent (AKD) particles were composed of alkanoate, bacterial spores of Bacillus cohniirelated strains and growth-required nutrients (i.e., yeast extract). Alkanoate-rich biomass was obtained from a pilot plant that uses the organic fraction of municipal waste (OFMSW) as raw material (Orgaworld/Paques, Lelystad,
TABLE 3 | Composition of samples analyzed through isothermal calorimetry.

\begin{tabular}{lccc} 
Specimen label & Cement type & Water/cement & $\begin{array}{c}\text { HA (\% by mass } \\
\text { of cement) }\end{array}$ \\
\hline Ctrl & CEM I & 0.5 & 0 \\
PLA & CEM I & 0.5 & 2.6 \\
AKD & CEM I & 0.5 & 2.6
\end{tabular}

Netherlands). Under laboratory conditions alkanoate was extracted from the biomass with a solvent-based method. Healing agent (HA) particles were obtained by merging together alkanoate, bacterial spores and growth requiring nutrients (i.e., yeast extract) through compaction. More information about the formulation of AKD particles can be found elsewhere (Vermeer et al., 2021). PLA-based healing agent obtained from Basilisk B.V. (Delft, Netherlands) was composed of lactate derivatives, bacterial spores of Bacillus cohnii-related strains and nutrients. Prior to be tested, both the healing agent particles were grinded and sieved to a dimension of $0.5-1 \mathrm{~mm}$. The composition of the healing agent particles are reported in Table 2 .

\section{Cement Hydration, Compression Strength and Setting Time}

The effect of the healing agents on the hydration of ordinary Portland cement (OPC, CEM I 42.5 N, ENCI, Rotterdam, Netherlands) was investigated through isothermal calorimetry test. The heat released during cement hydration was monitored for around two days through an eight-channel isothermal calorimeter (TAM Air 3114/2326, thermometric AB, Sollentuna, Sweden), operating at $600 \mathrm{~mW}$ and at $20 \pm 0.02^{\circ} \mathrm{C}$. In each calorimeter glass ampoule, $2.5 \mathrm{~g}$ of cement were mixed with water to obtain a water to cement ratio (w/c) of 0.5 . PLA and AKD particles were separately added to the paste at $2.6 \%$ by mass of cement. One reference sample (Ctrl) for each cement type was also analyzed without any HA addition. For each sample composition, two replicates were tested. The first hour of heat flow measurements were subtracted from the heat curve since they were related to the stabilization of the sample inside the calorimeter. Specific sample composition is visible in Table 3. 
TABLE 4 | Mixing proportions of mortar specimens per $\mathrm{kg}$ of mixture.

\begin{tabular}{lc}
\hline Ingredients & Weight $(\mathbf{g})$ \\
\hline CEM I 42.5 N & 220.9 \\
Water & 110.5 \\
Aggregates $(0.125-2 \mathrm{~mm})$ & 662.7 \\
Healing agent $(0.5-1 \mathrm{~mm})$ & $5.9^{\mathrm{a}}$
\end{tabular}

${ }^{a}$ Only for bacteria-based specimens.

\begin{tabular}{|c|c|c|c|c|}
\hline & $2-1 \mathrm{~mm}$ & $1-0.5 \mathrm{~mm}$ & $0.5-0.25 \mathrm{~mm}$ & $0.25-0.125 \mathrm{~mm}$ \\
\hline Percentage (\%) & 33 & 34 & 21 & 12 \\
\hline Quantity (g) & 218.7 & 225.3 & 139.2 & 79.5 \\
\hline
\end{tabular}

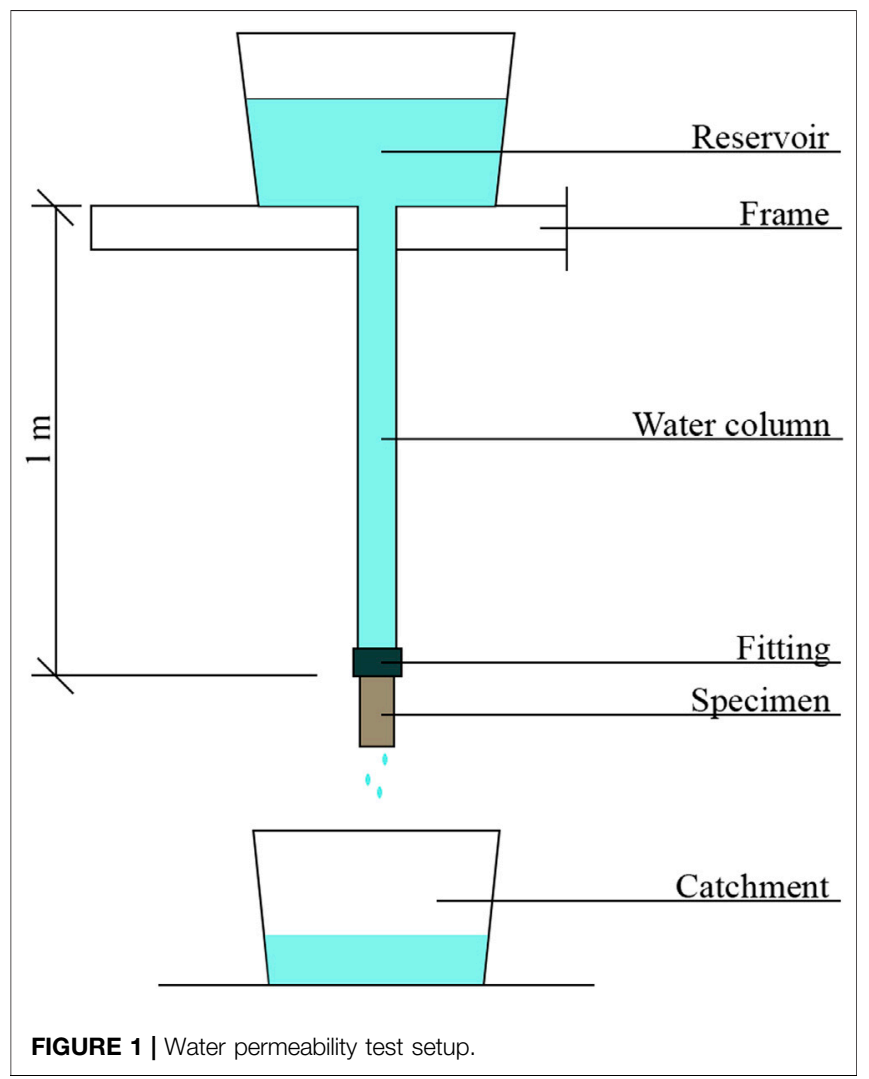

Three series of $40 \times 40 \times 40 \mathrm{~mm}^{3}$ mortar cubes were cast with Ordinary Portland cement (OPC, CEM I 42.5N, ENCI, The Netherlands), a water/cement ratio of 0.5 and fine siliceous aggregates $(0.125-2 \mathrm{~mm})$. The three series have been labelled as follows: Ctrl for plain mortar, PLA for OPC mortar with $2.6 \%$ by mass of cement of PLA-based healing agents and AKD for OPC mortar with $2.6 \%$ by mass of cement of alkanoates-derived healing agent. Mortar cubes have been cast and sealed with plastic foil for $24 \mathrm{~h}$ before getting de-moulded. Uniaxial compression test has been conducted at $1,3,7$ and 28 days of curing, which occurred in a high humidity chamber $(\mathrm{RH}>95 \%)$. Mixing proportions of mortar specimens are reported in Tables 4, 5 . The initial and final setting time of the same mixtures (Ctrl, PLA and $\mathrm{AKD}$ ) was also tested through the Vicat test, according to EN 196-3.

\section{Self-Healing Capacity}

The self-healing capacity of specimens cast with Ctrl, PLA and AKD mixtures (Tables 2, 3) has been also tested. Cylinders of $35 \mathrm{~mm}$ in diameter and $60 \mathrm{~mm}$ high were cast for each mortar mix. The specimens were cast with two lateral notches to facilitate the induction of cracks (Figure 1). After $24 \mathrm{~h}$ curing, specimens were carefully de-moulded, tightly sealed in plastic foil to avoid evaporation of water, and kept at room temperature for further curing. For each mortar mixture, three specimens were cracked through a splitting test at 28 days after casting (labelled as Ctrl28d, PLA-28d and AKD-28d for each specific mixture), while three more specimens were cracked at 6 months after casting (labelled as Ctrl-6m, PLA-6m and AKD-6m). After cracking, two plastic spacers were placed at the notches to keep the distance between the two halves of the sample equal to approximately $0.4 \mathrm{~mm}$, and the sides of the samples were carefully sealed with tape and silicone.

The self-healing capacity (SHC) of control and bacteria-based mortar specimens was evaluated through crack calibration and water permeability as proposed by Palin et al. 2016, of which setup is visible in Figure 1. After crack induction and calibration, specimens were attached via a fitting at the bottom of each water column, which were $1 \mathrm{~m}$ high. The test was initiated by releasing the taps in each reservoir, which released tap water that could penetrate into the cracked specimens. The level of the water in the column was kept constant manually, ensuring a pressure of around 0.1 bar. Water flowing through the cracks was individually collected in catchment buckets and the weight of the water recorded every $5 \mathrm{~min}$ for a total test duration of $15 \mathrm{~min}$. Following the permeability test conducted just after crack induction, specimens were kept under self-healing conditions in a high humidity room ( $\mathrm{RH}>95 \%)$ for 56 days. After the healing period, optical microscope (Leica MZ6, Nussloch, Germany) images of the surface cracks were collected and compared to those before the healing period, and the water permeability test was conducted again.

The self-healing capacity of specimens, SHC, was calculated according to (Eq. 1):

$$
\mathrm{SHC}=\left[\left(\mathrm{Q}_{0}-\mathrm{Q}_{\mathrm{h}}\right) / \mathrm{Q}_{0}\right] * 100
$$

Where $\mathrm{Q}_{0}$ is the initial water flow $\left(\mathrm{cm}^{3} / \mathrm{s}\right)$ measured just after cracking (i.e., 0 days of healing) and $\mathrm{Q}_{\mathrm{h}}$ is the water flow after 56 days of healing $\left(\mathrm{cm}^{3} / \mathrm{s}\right)$.

\section{Mineral Formation}

Besides optical microscope analysis of surface cracks, ESEM analysis of precipitates in the crack depth was also conducted. After conducting the water permeability test, cylinders were impregnated with fluorescent epoxy resin and sawn perpendicularly to the crack. After sawing, the surface of the sawn samples was again impregnated with epoxy resin. Samples 


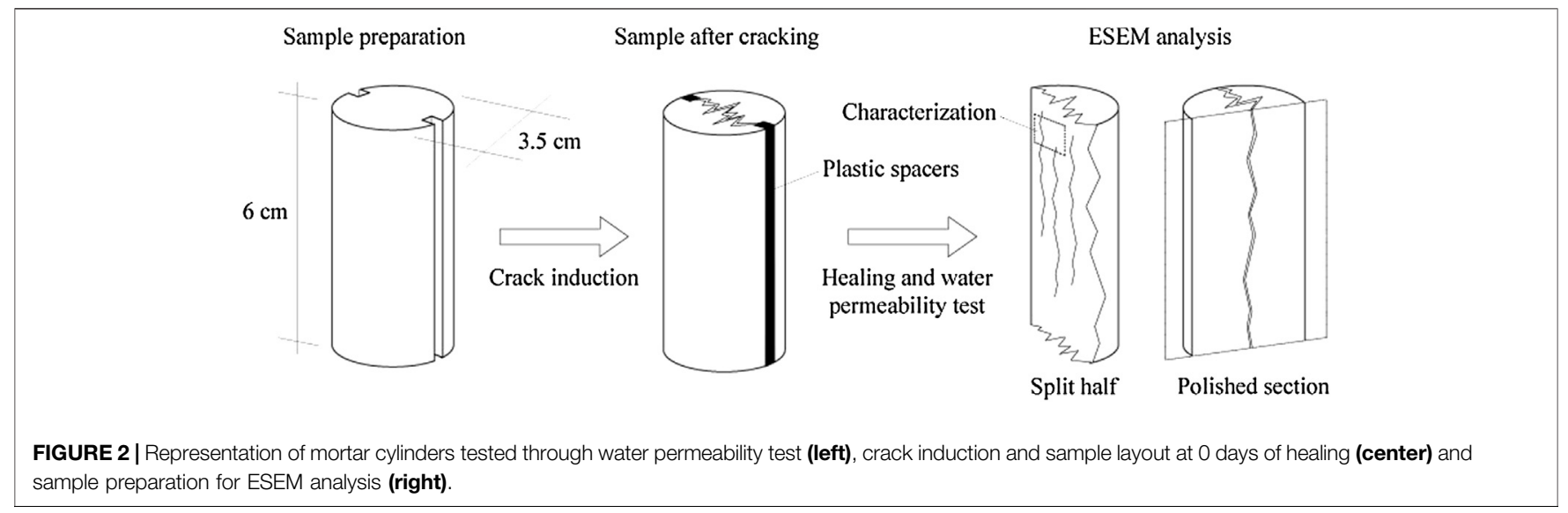

TABLE 6 | Amount of separate components included in each flask analyzed through non-invasive oxygen sensors.

\begin{tabular}{|c|c|c|c|c|}
\hline Flasks & Buffer solution (mg) & Bacteria spores (mg) & Yeast extract (mg) & Alkanoate (mg) \\
\hline F-Ctrl & 46.0 & - & - & - \\
\hline F-Bact & 46.0 & 0.5 & - & - \\
\hline F-YE & 46.0 & 0.5 & 2.4 & - \\
\hline F-AKD & 46.0 & 0.5 & - & 116.7 \\
\hline F-AKD-HA-LO & 46.0 & 0.5 & 2.4 & 116.7 \\
\hline F-AKD-HA-P & 46.0 & 0.5 & 2.4 & 116.7 \\
\hline
\end{tabular}

were manually ground with \#120, \#220, \#320, \#600, \#800 and 1200\# grinding Silicone Carbide sanding paper and polished with $6,3,1$ and 0.25 um polishing diamond paste on a lapping table to obtain a mirror-like surface of the specimens. Each grinding and polishing step took around $10 \mathrm{~min}$. Ethanol and non-water based polishing paste were used for grinding and polishing, respectively, to avoid further on-going hydration of the sample. ESEM analysis (Philips XL30 Series) under Back-scatter electron mode (BSE) of the polished section obtained perpendicularly to the crack was then conducted. A representation of the specimen preparation for each analysis is reported in Figure 2.

\section{Evidence of Bacterial Activity}

Since aerobic metabolic conversion of nutrients consumes oxygen, bacterial metabolic activity in concrete can be indicated by an oxygen reduction in the concrete matrix or in a simulated concrete environment (Mors and Jonkers, 2017a). In this study, non-invasive oxygen concentration measurements have been conducted through an oxygen sensitive sensor (PSt3 sensor, Fibox 4 transmitter, PreSens, Regensburg, Germany), as proposed by previous researches (Wiktor and Jonkers, 2011 and Mors and Jonkers, 2017a). In this test, the oxygen consumption inside six flasks embedding different components was monitored. Flasks of around $15 \mathrm{ml}$ have been partially filled with $0.05 \mathrm{M}$ sodium carbonate bicarbonate buffered ( $\mathrm{pH}$ 10.5) water, leaving a headspace of around $10 \mathrm{ml}$. The control flask (F-Ctrl) contained $5 \mathrm{ml}$ of buffer solution only. In two further flasks, $0.4 \mathrm{mg}$ of bacteria spores with and without $2.4 \mathrm{mg}$ of yeast extract were added (labelled as F-YE and F-Bact, respectively). In F-AKD, bacteria spores $(0.5 \mathrm{mg})$ and alkanoates $(116.7 \mathrm{mg})$ were added without including any growth-required nutrients. Two more flasks were prepared including all the components of the proposed healing agent. Firstly, $116.7 \mathrm{mg}$ of alkanoates were added to $0.4 \mathrm{mg}$ of spores and $2.4 \mathrm{mg}$ of yeast extract as loose components (labelled as F-AKD-HA-Lo). Finally, $120 \mathrm{mg}$ of healing agent particles (i.e., after merging the loose components through compaction) were included in the flask (labelled as F-AKD-HA-P). In F-AKD-HA-Lo and F-AKD$\mathrm{HA}-\mathrm{P}$, the total concentration of healing agent was $2.6 \mathrm{~g} / \mathrm{L}$ of buffer solution. The content of components included in each flask are reported in Table 6.

Evidence of bacterial activity in the concrete matrix has been also evaluated through ESEM analysis, as previously conducted by (Tziviloglou et al., 2016b). Specimens previously tested through water permeability test were split in two halves and $\mathrm{CaCO}_{3}$ crystals were microscopically characterized, as schematically represented in Figure 1. A complete overview of the whole experimental plan is schematically represented in Figure 3.

\section{RESULTS}

\section{Cement Hydration, Compression Strength and Setting Time}

Results about the effect of healing agents on the hydration, compression strength and setting time of mortar are visible in Figure 4 and Table 7. 

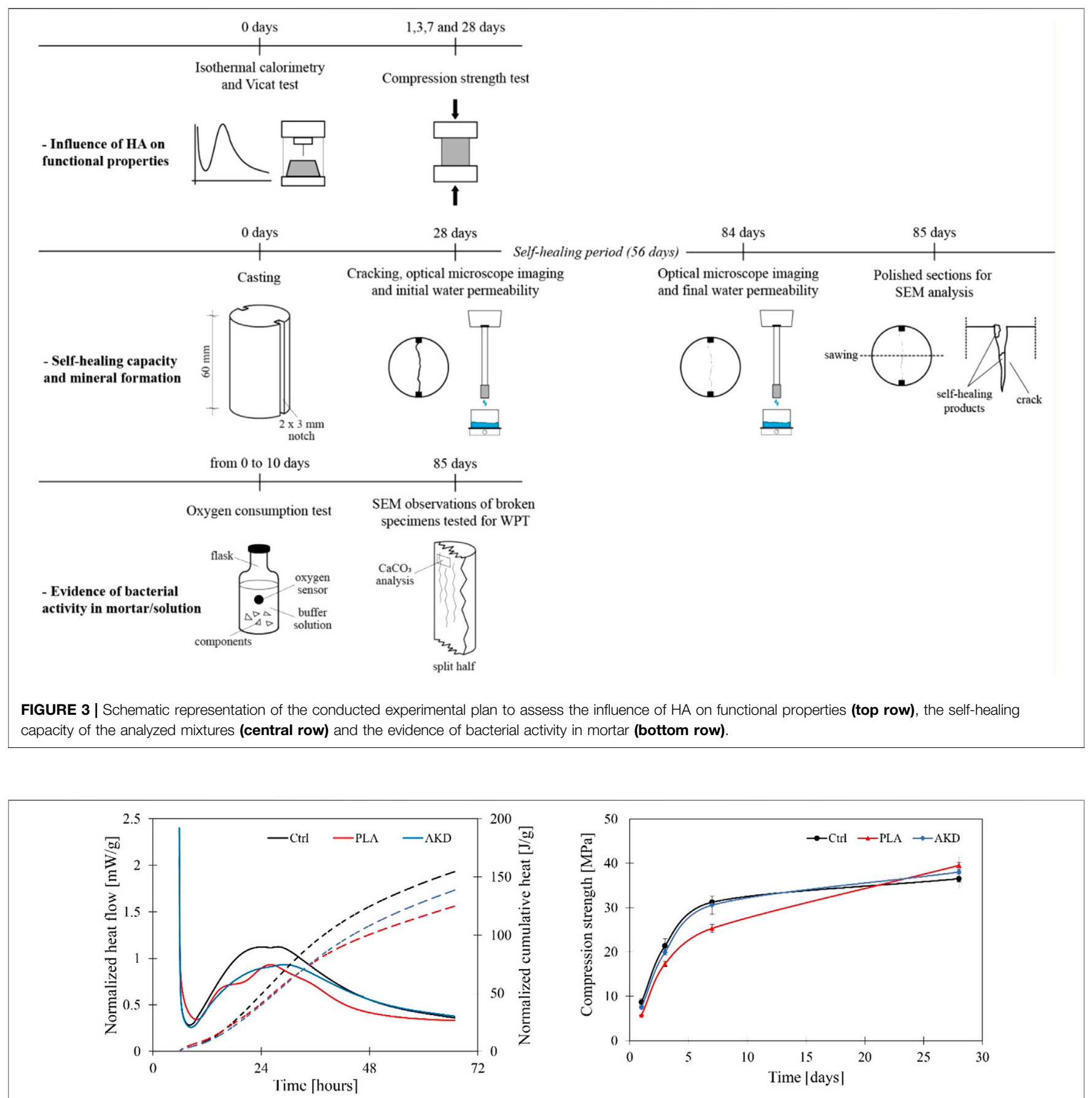

FIGURE 4 | Isothermal calorimetry test (left) and compression strength of mortar at 1, 3, 7 and 28 days (right).

TABLE 7 | Initial and final setting time (average of three replicates).

\begin{tabular}{lcccc}
\hline & $\begin{array}{c}\text { Initial } \\
\text { setting time (min) }\end{array}$ & STD & $\begin{array}{c}\text { Final } \\
\text { setting time (min) }\end{array}$ & STD \\
\hline Ctrl & 162 & 16 & 226 & 10 \\
PLA & 172 & 8 & 232 & 12 \\
AKD & 185 & 38 & 252 & 15 \\
\hline
\end{tabular}

In Figure 4, it is visible that the addition of both PLA and AKD cause a decrease of heat developed by the hydration of OPC. During the first $10 \mathrm{~h}$ (induction or dormant phase), the heat released by the PLA samples is slightly higher than that of the others, while no relevant differences can be seen between Ctrl and AKD. Ctrl releases the highest amount of heat during the acceleration period (between 10 and $20 \mathrm{~h}$ ), reaching more than 


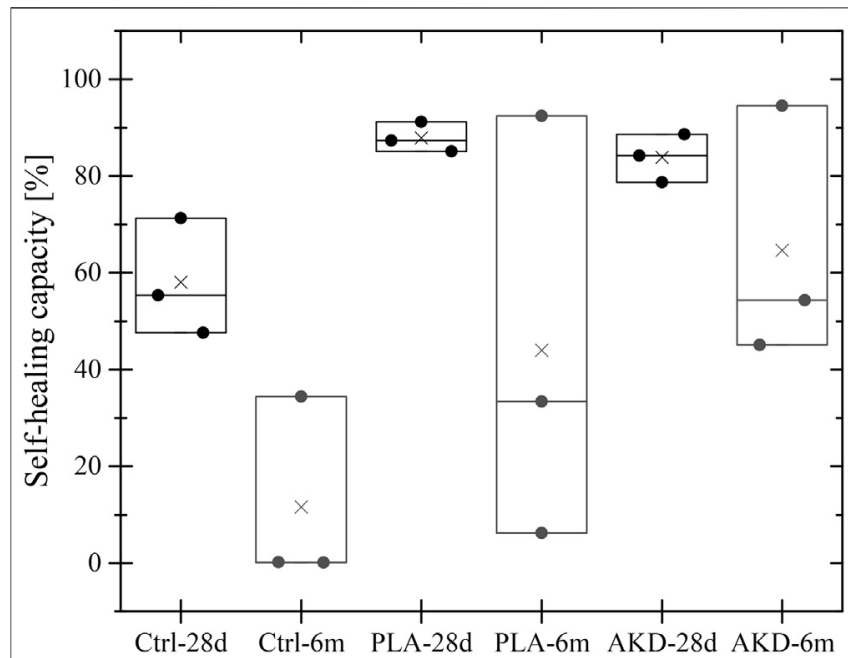

FIGURE 5 |Boxplot about water permeability test of specimens cracked at 28 days $(X-28 d)$ and 6 months $(X-6 m)$. Individual measurements are showed by dots, while the average value for each series is shown by crosses. The middle bar is representative for the median value, while the top and bottom bars are representative for the maximum and minimum value of each series, respectively.

$1 \mathrm{~mW} / \mathrm{g}$. Lower heat is released by both PLA and AKD samples, as noticeable by the normalized cumulative heat curve. The heat flow of both Ctrl shows two shoulders at around 22 and $26 \mathrm{~h}$, which are related to the hydration of OPC (Neville, 1995). Similar shoulders are visible for AKD heat flow also, but with lower heat released equal to around $0.8 \mathrm{~mW} / \mathrm{g}$. For PLA, the progress of heat flow is influenced by the inclusion of the healing agent since the curve shows three defined peaks, which cannot be observed in other samples. According to the conducted compression test (Figure 4), Ctrl and AKD series show very similar strength development at any age of testing, with a 28-days compression strength equal to 36.5 and $38 \mathrm{MPa}$, respectively. Differently, a reduction of $35.1,19.0$ and $19.1 \%$ compared to the compression strength the Ctrl series can be observed upon the addition of PLA in mortar at 1, 3 and 7 days, respectively. Nevertheless, the 28days compression strength of PLA-based specimens, $39.5 \mathrm{MPa}$, was slightly higher than that of both Ctrl and AKD. Limited influence upon the addition of both the healing agents is also visible for the initial and final setting time of mortar. The initial setting time of OPC-mortar is slightly delayed due to the inclusion of the healing agents in the matrix by 10 and $23 \mathrm{~min}$ for PLA and AKD, respectively. A time difference between initial and final setting time of around 60-65 min occurred for all the three mixtures.

\section{Water Permeability Test}

The self-healing capacity of control and alkanoate-based specimens measured at 56 days of healing for specimens cracked at 28 days and 6 months after casting is shown in Figure 5.

According to Figure 5, the SHC of specimens cracked at 28 days after casting was higher than that of specimens cracked at
6 months after casting. On average, a SHC of 58.1, 87.8 and $83.8 \%$ for Ctrl-28d, PLA-28d and AKD-28d have been measured. For specimens cracked at 6 months after casting a significant drop of SHC is visible, since average SHC of $11.6,44.0$ and $64.6 \%$ were measured for Ctrl-6m, PLA-6m and AKD-6m, respectively. For specimens cracked at 28 days after casting, the variation of results is narrower than that of specimens cracked at 6 months age. The differences between maximum and minimum values of SHC for each 28 days-cracked series are 23.7, 6.1 and 9.9\% for Ctrl-28d, PLA-28d and AKD-28d, respectively. On the contrary, 34.4, 86.2 and $49.4 \%$ have been measured for Ctrl-6m, PLA-6m and AKD$6 \mathrm{~m}$, respectively. PLA $-6 \mathrm{~m}$ and AKD-6m showed the highest values of SHC, with a maximum value of 92.4 and $94.5 \%$, respectively. Similarly, PLA-28d and AKD-28d had maximum values of SHC equal to 91.2 and $88.6 \%$. Lower SHC has been measured for Ctrl-28d and Ctrl-6m, with maximum values equal to 71.3 and $34.4 \%$, respectively.

\section{Mineral Formation}

In Figure 6, optical microscope images $(1 \times$ magnification $)$ of the surface cracks before and after 56 days of self-healing are shown.

For plain mortar specimens (Figures 6A,D), it is visible that partial surface crack-healing occurred for Ctrl-28d while no significant healing products can be observed for Ctrl-6m. Differently, specimens with added-in PLA and AKD (Figures 6B,C,E,F) show complete healing of the crack surface at 56 days after cracking, regardless the time at which pre-cracking occurred. As visible in Figures 6E,F, the layer of healing products of AKD- $6 \mathrm{~m}$ looks qualitatively thinner than that of PLA-6m, nevertheless completely healing the crack mouth.

Beside optical microscope analysis of the crack surface, ESEM analysis of the precipitates getting formed in the crack depth has been also conducted. Polished sections perpendicular to the crack of one sample for each series are reported in Figures 7, 8.

For Ctrl-28d (Figure 7B), a thin layer of precipitates is visible at the crack mouth, which does not cover the whole crack width. Very limited amount of crystals formation is visible at the edges of the crack. At around $20 \mathrm{~mm}$ deep in the crack (Figure 7A), only isolated crystals at the crack sides can be observed. For PLA-28d (Figure 7D), minerals almost completely seal the whole crack mouth. A thin layer of minerals is visible between around 1 and $3 \mathrm{~mm}$ deep in the crack. At around $3.5 \mathrm{~mm}$ in the crack depth, relatively high precipitation of minerals which almost fill the sides of the crack is visible. Similarly, precipitates that seal the sides of the crack can be observed at $20 \mathrm{~mm}$ deep in the crack (Figure 7C). The highest amount of precipitates inside the crack is qualitatively visible for AKD-28d (Figure 7F). The crack mouth is completely healed by a thin layer of precipitates of around $40-50 \mu \mathrm{m}$ thick. Down to around $2 \mathrm{~mm}$ inside the crack, high precipitation of crystals that almost completely filled the crack is visible. Deeper than $2 \mathrm{~mm}$ from the crack mouth, the amount of precipitates considerably decreases and layers of around 20-40 um of precipitates can be observed down to about $4 \mathrm{~mm}$ deep in the crack. Similarly to what can be observed for PLA-28d, at around $20 \mathrm{~mm}$ deep in the crack precipitates that seal the crack sides can be observed also for AKD-28d (Figure 7E). 

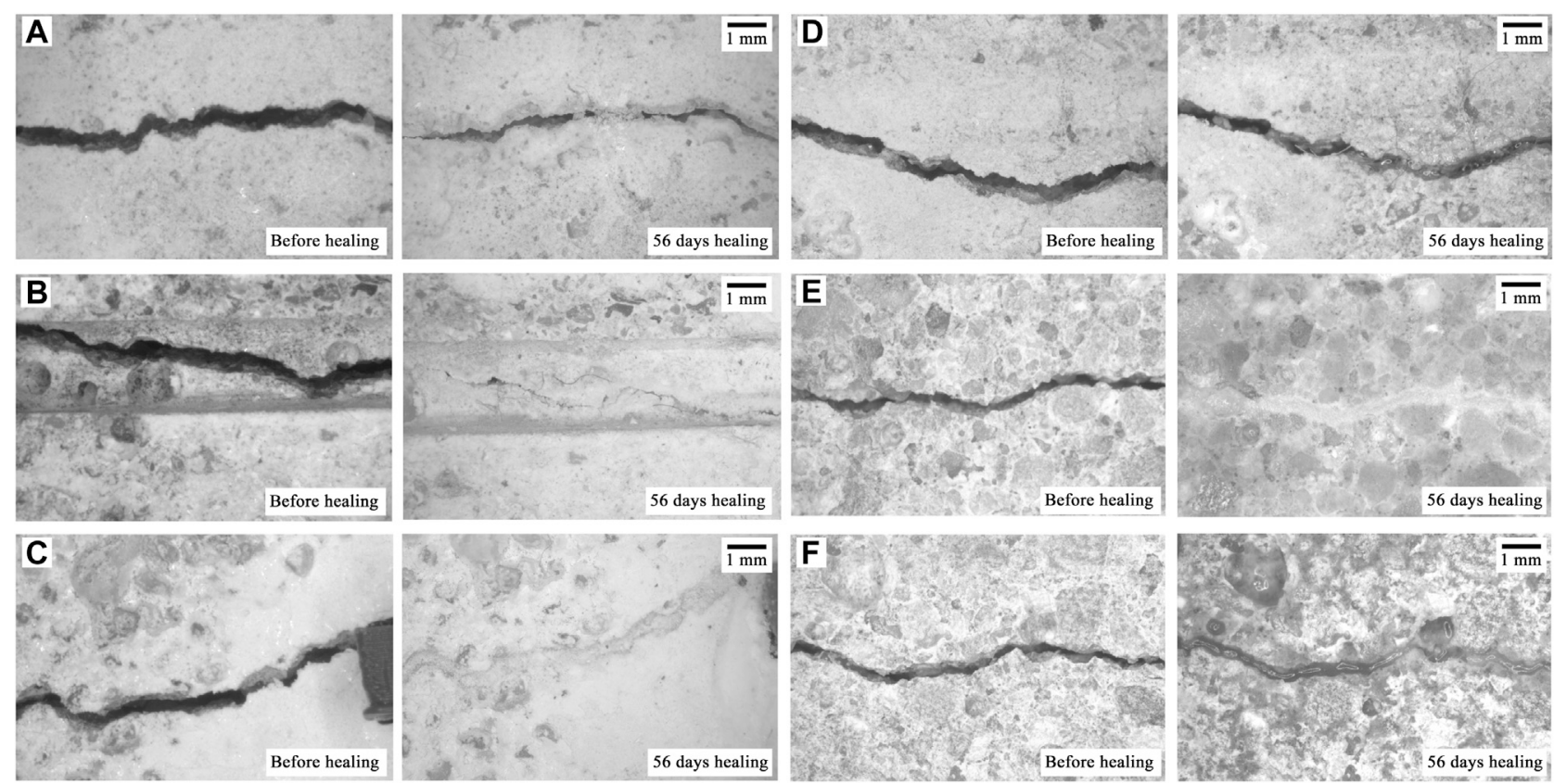

FIGURE 6 | Optical microscope images of cracked specimens before and after 56 of healing incubation. One specimen for each series tested through water permeability test is reported (a for Ctrl-28d, b for PLA-28d, c for AKD-28d, d for Ctrl-6m, e for PLA-6m, f for AKD-6m).

Similarly to Ctrl-28d (Figures 7A,B), for Ctrl-6m relatively thin and isolated precipitates can be observed at both the crack mouth (Figure 8B) and at around $20 \mathrm{~mm}$ deep in the crack (Figure 8A), which cannot seal the sides of the crack. On the contrary, for PLA- $6 \mathrm{~m}$ a thin layer of precipitates that heal the crack mouth is visible (Figure 8D). At around $20 \mathrm{~mm}$ deep in the crack, the sides of the crack get also sealed by precipitates (Figure 8C). Compared to PLA-6m, less precipitates are visible at the crack mouth of AKD- $6 \mathrm{~m}$ (Figure 8F) which do not completely seal the sides of the crack. The crack gets partially sealed at the crack mouth by precipitates and at $3 \mathrm{~mm}$ depth by precipitates and aggregates. For both specimens, the cracks get sealed at around $3 \mathrm{~mm}$ deep in the crack (Figure 8F) as well as the around $20 \mathrm{~mm}$ in depth (Figure 8E).

\section{Evidence of Bacterial Activity}

The results of the oxygen consumption test by bacteria in a concrete-simulating solution measured through non-invasive oxygen sensitive sensors are reported in Figure 9.

According to the results of the oxygen consumption test reported in Figure 9, the activity of bacteria consuming AKD can be observed. It is indeed noticeable how for flasks with no addition of growth-required nutrients nor alkanoates (i.e., F-Ctrl and F-Bact) the oxygen concentration stays overall constant at around $20 \% \mathrm{O}_{2}$. F-AKD, despite a slight drop at around $120 \mathrm{~h}$, also showed a constant concentration of $\mathrm{O}_{2}$ inside the flask, suggesting that growth-required nutrients are necessary for the consumption of the substrate. For F-YE, the $\mathrm{O}_{2}$ concentration has a gradual drop between 72 and $120 \mathrm{~h}$, then stabilizing at around $15 \% \mathrm{O}_{2}$. Results of F-YE suggest that oxygen is partially consumed by the germination of bacterial spores, which however cannot completely consume the oxygen in the flask due to the lacking of substrate. Complete consumption of $\mathrm{O}_{2}$ is visible for F-AKD-HA-Lo and F-AKDHA-P, which suggests that the substrates gets consumed by bacteria given the presence of the growth-required nutrients as much as there is oxygen in the flask. It appears clear that F-AKD-HA-Lo has a steeper drop to $0 \% \mathrm{O}_{2}$ than that of F-AKD-HA-P, which might be attributed to the particle formulation. Indeed, since for F-AKD-HA-P merged particles have been added to the flask, it is likely that penetration of water to activate the bacteria was slightly delayed by the fact that water had to penetrate into the particle matrix. On the other hand, for F-AKD-HA-Lo the healing agent components were added as loose, hence being more easily available for activation and consumption of oxygen, therefore implying a steeper drop of $\% \mathrm{O}_{2}$. Nevertheless, the results of F-AKD-HA-P suggest that the substrate can be metabolized by bacteria in a concrete-simulated environment also when components are embedded in the particle matrix.

Further observations were conducted on freshly-broken halves of self-healed specimens to demonstrate the bacterial activity in the matrix. Figure 10 shows crystals with likely surface bacteria imprints which provide evidence of bacterial activity in concrete, as already pointed out by previous studies (Tziviloglou et al., 2016b). Based on the rhombohedral shape, the observed crystals are likely to be calcite, which would highlight the compatibility between bacterial metabolic activity and self-healing of Ordinary Portland-based mortar specimens through the addition of AKD. 

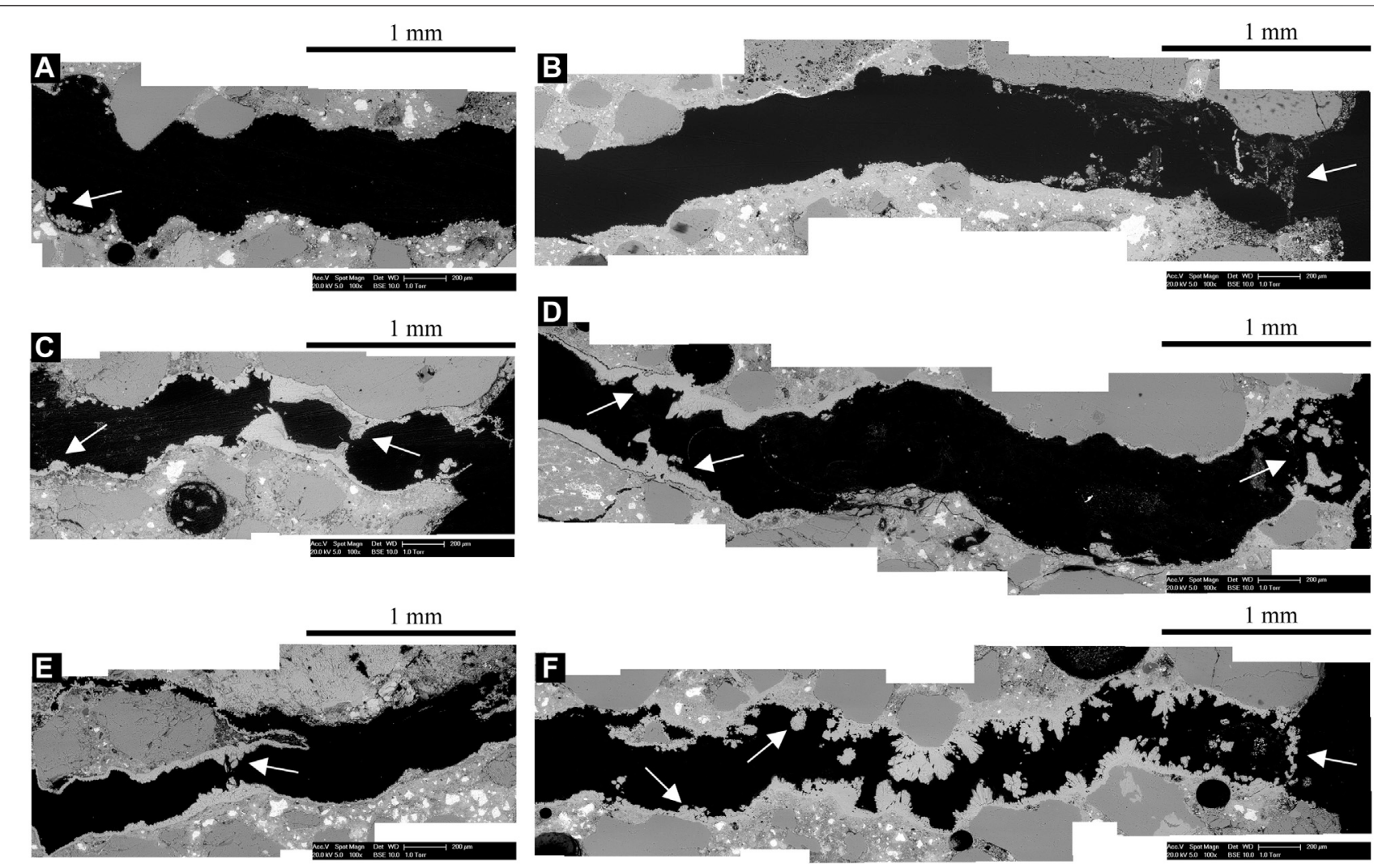

FIGURE 7 | Polished sections perpendicular to the crack under ESEM/BSE of (A,B) Ctrl-28d plain mortar, (C,D) PLA-28d and (E,F) AKD-28d specimens (precipitates are indicated by white arrows). B, D and $\mathbf{F}$ are representative for the crack mouth of each specimen. A, C and $\mathbf{E}$ are micrographs taken at around $20 \mathrm{~mm}$ depth perpendicularly to the crack.

\section{DISCUSSION}

\section{Cement Hydration, Compression Strength and Setting Time}

The influence of PLA and AKD healing agents on the hydration of OPC, the compression strength and setting time of OPCmortar was tested in this study. According to the isothermal calorimetry test, it can be seen that lower energy is released by both pastes with added-in PLA and AKD agents, as noticeable by the normalized cumulative heat curve reported in Figure 4. For PLA and AKD, two different behaviors can be noticed. For PLA, the energy released by the hydration of OPC as well as the progress in time of the hydration curve are different than the Ctrl. The latter characteristic might be due to a chemical interaction between the PLA-based particles and the cement. According to previous studies on the influence of organic compounds on cement hydration (Taplin, 1960), the alkaline degradation of organic compounds into molecules containing the a-hydroxy carboxyl group may be responsible for their strong absorption and therefore having a retardation effect. Even though there are contradictory opinions about the influence of the a-hydroxy carboxyl group on cement hydration (Singh et al., 1986; Schultz, 1987), the results of the present study confirms the retarding effect of the employed concentration of PLA and AKD (i.e., 2.6\% by mass of cement) (Rodriguez et al., 2020). This point is supported by both the lower energy released during the hydration of cement as well as the delay in setting time of PLA- and AKD-based mortar compared to that of OPC-mortar, which is equal to 10 and $23 \mathrm{~min}$, respectively. For AKD, a decrease heat developed by the hydration of OPC can be observed, but the heat flow progress is similar to that of OPC, which might not be related to any chemical interaction with the cement components. It might be the case that, since AKD particles are porous and hygroscopic, the might absorb water, partially preventing this to react with cement grains and therefore reducing the heat flow. Another possible explanation might be that AKD particles around the cement grains partially reduce the surface of cement grains that can react with water. Nevertheless, from the compression test (Figure 3, right) it can be seen that this effect on cement hydration can be considered negligible at least in terms of influence on mechanical properties of OPC-mortar, since no detrimental effect is caused by the addition of AKD in the matrix at any age up to 28 days. On the other hand, the inclusion of PLA-based healing agent in OPC mortar caused a decrease of $20-35 \%$ for early 


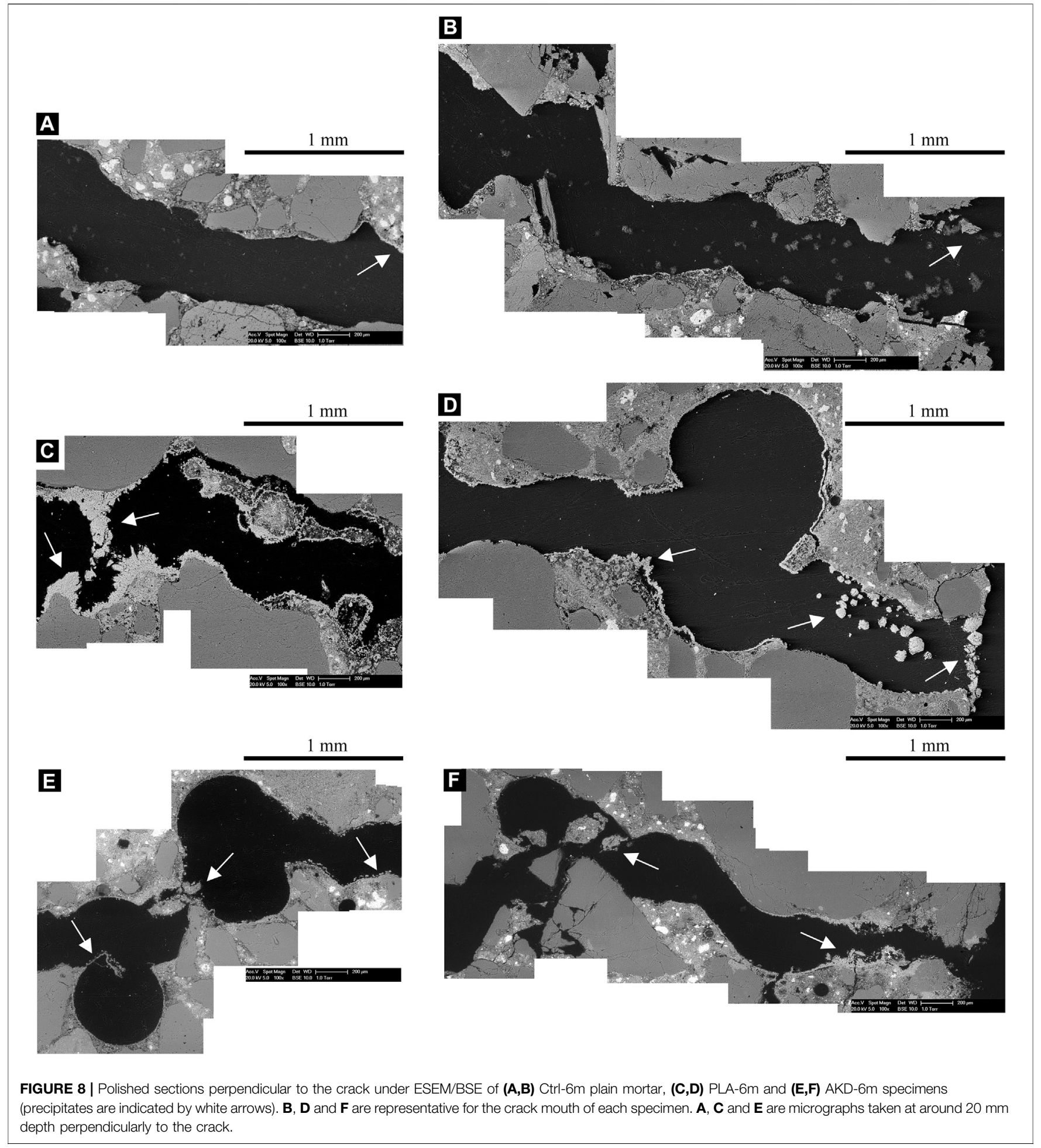

stage compression strength (i.e., until 7 days after casting), which might further suggest a chemical interaction between PLA and cement hydration, as previously discussed. Nevertheless, the compression strength of PLA-based mortar at 28 days results slightly higher than that of plain OPC, suggesting no detrimental influence on the long-term functional properties.

\section{Water Permeability Test and Self-Healing Capacity}

According to Figure 5, the self-healing capacity of plain mortar (Ctrl) appeared to be clearly improved by the addition of the proposed healing agent. For specimens cracked at 28 days age, the SHC of Ctrl$28 \mathrm{~d}$ was improved by $51 \%$ and $44 \%$ upon the addition of PLA and 


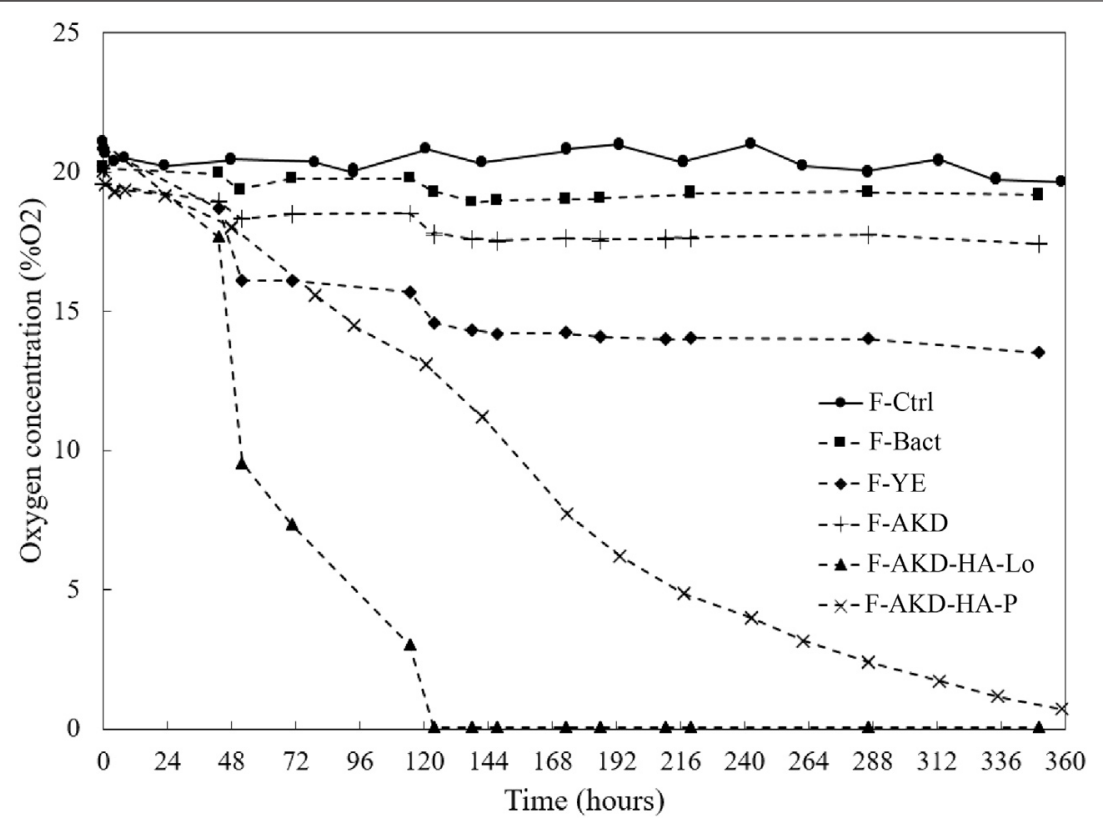

FIGURE 9 | Results of non-invasive oxygen consumption test.
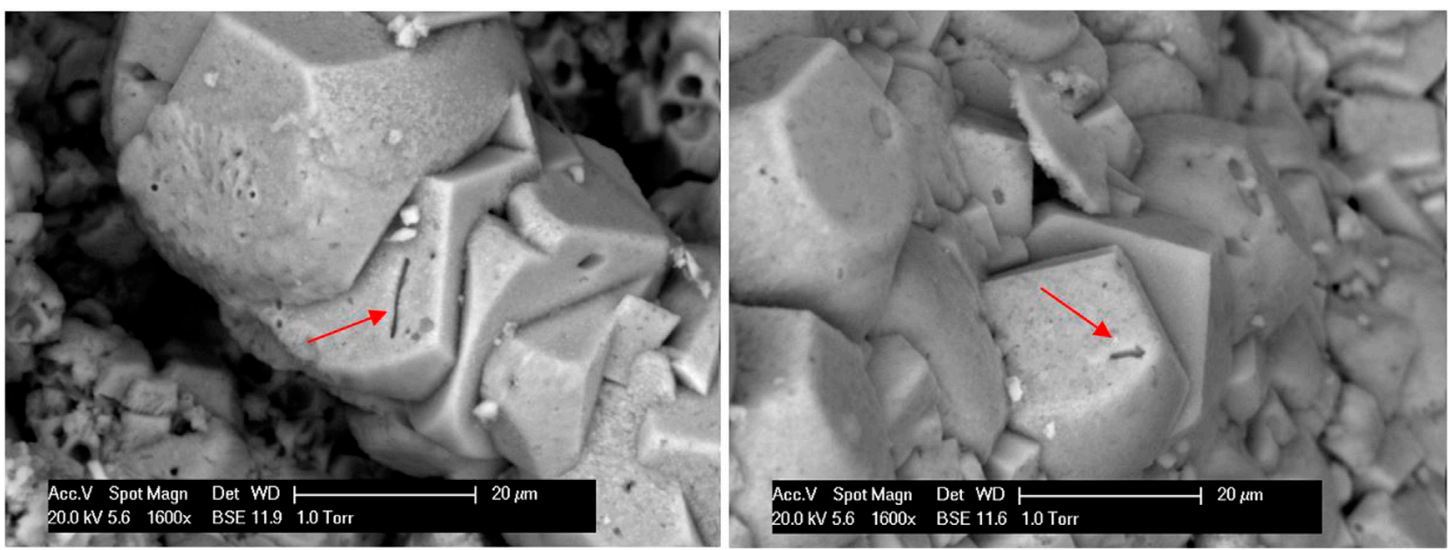

FIGURE 10 | Calcite crystals observed through ESEM analysis of the freshly-split cylinders after 56 days of healing with surface bacterial imprints (indicated by arrows).

$\mathrm{AKD}$ healing agents, respectively. Higher improvements can be observed for the series cracked at 6 months age, for which the SHC of Ctrl-series was improved by a factor of 4 and 6 thanks to the addition of PLA and AKD, respectively. The age of pre-cracking is a fundamental aspect to consider when studying self-healing mechanisms of concrete (Ferrara et al., 2018). Autogenous healing of concrete is the result of mostly the rehydration of un-hydrated cement grains and of the precipitation of calcium carbonate due to carbonation. The former mechanism is the dominating factor for selfhealing of concrete cracked at an early stage (i.e., 28 days after casting), since there is still significant amount of un-hydrated cement particles (Neville, 2002; Van Tittelboom and De Belie, 2013). The latter mechanism is the dominating factor for self-healing of concrete cracked at a later stage (Neville, 2002), and it is related to the environment and its humidity in which the specimens are stored during the healing period. The results of the present study are in line with this theoretical background. For specimens cracked at 28 days, the SHC of Ctrl was equal to $58.1 \%$, while for specimens cracked at 6 months age the SHC was equal to $11.6 \%$. These results suggest that specimens cracked at an age of 6 months have more limited amount of un-hydrated cement particles that can stimulate self-healing of concrete, which is in line with previous researches (Luo et al., 2015). Similar but less accentuated drop in SHC depending on the time of pre-cracking can be observed also for PLA and AKD series. PLA-28d and AKD-28d had average values of SHC equal to 87.9 and $83.3 \%$, respectively, while PLA- $6 \mathrm{~m}$ and AKD-6m had average values of SHC 
equal to 44.0 and $64.6 \%$, respectively. These results suggest that specimens cracked at 28 days age could self-heal thanks to the combination of autogenous self-healing, carbonation as well as precipitation of calcium carbonate triggered by the addition of the healing agents, resulting in almost completely recover the water tightness of cracked specimens. For specimens cracked at 6 months age, the amount of un-hydrated cement particles that can contribute to the self-healing of cracks would be reasonably lower than that of specimens cracked at 28 days age. Hence, the self-healing capacity for specimens cracked at 6 months age decreased since it would rely on bacteria-induced precipitation and carbonation, mitigating the effect of autogenous healing. Nevertheless, the selfhealing capacity of mortar with added-in PLA and AKD were respectively 4 and 6 times higher than that of the Ctrl series. Since the specimens were cured and healed under identical environmental conditions, the higher SHC of bacteria-based mixtures can be likely attributed to the precipitation of healing crystals triggered by bacterial activity in concrete. As a matter of fact, these results demonstrate the improved SHC of bacteria-based specimens compared to the Ctrl series regardless the age of precracking as well as the compatibility between the concrete (alkaline) environment and bacterial metabolic activity for both short and long periods. This latter fact suggests that the viability of the proposed healing agent would not be compromised by staying embedded in the matrix for a (dormant) period of several months.

The SHC of plain mortar cracked at 6 months was overall enhanced by a factor of around 4 and 6 when PLA-based and AKD were added-in the mixture, respectively. However, the results variation for the series cracked at 6 months age is considerably higher than that of specimens cracked at 28 days. The minimum SHC measured for PLA-6m was equal to $6.3 \%$, which is lower than the maximum SHC measured for Ctrl-6m (equal to $34.4 \%$ ) and therefore would not improve the self-healing capacity of plain mortar. Differently, the minimum SHC for AKD was equal to $45.1 \%$, which is higher than the SHC of Ctrl-6m but still not significantly improving its ability to self-heal cracks. Two possible explanations might be given for such an uneven distribution of results. Firstly, the distribution of the healing agent particles in the matrix might be uneven since it gets added-in while mixing. Since the two systems analyzed in study are based on aerobic activity of bacteria, the oxygen-rich crack mouth is likely where most of the calcium carbonate precipitation would happen, enhancing the SHC of mortar. Lack of self-healing agent particles in proximity to the crack mouth might have mitigated the surface precipitation and consequent closure of the cracks. If this was the case, concentrating the healing agent particles at the surface of the specimens might be a favorable solution to surely enhance the SHC of surface cracks. The second possible explanation is about the healing agent particles formulation. Indeed, in both cases the substrate (PLA-derived or alkanoates-based), the growth requiring nutrients and the bacterial spores are mixed together and then particles are obtained through compaction. The overall proportions of each components are ensured, but the current process to obtain the healing agents does not guarantee that each particle has the same composition and, therefore, the same ability to trigger self-healing in concrete. This fact is of high importance especially since the present of growth-required nutrients is a fundamental component for the substrates to be consumed by bacteria. This fact is clearly demonstrated by the oxygen consumption test conducted in this study, according to which the flask containing bacteria spores and alkanoates with no nutrients (i.e., F-AKD) did not show any oxygen consumption in a concrete-simulated solution. In future studies, both the above-mentioned scenarios will be evaluated and improved, if necessary, to guarantee more consistent SHC.

\section{Mineral Formation}

According to ESEM analysis of polished sections, the mineral precipitation perpendicularly to the crack of healed specimens was visibly improved by the addition of both PLA- and AKDbased healing agents. At certain locations, a thin layer of precipitates that sealed the crack tip was always visible for specimens embedding PLA and AKD healing agents cracked at both 28 days and 6 months age. Precipitates that partially or completely sealed the sides of the crack could be observed also at around $20 \mathrm{~mm}$ deep in the crack. On the contrary, the Ctrl specimens had only thin and isolated precipitates both at the crack mouth and at around $20 \mathrm{~mm}$ deep in the crack, which could not seal the cracks. ESEM analysis of mineral precipitation in the crack depth suggests that self-healing occurs due to bacterial metabolic activity at certain locations, without sealing the cracks completely. For self-healing induced by bacteria, oxygen must be present for bacterial activity, a solution must be present to dissolve $\mathrm{CO}_{2}$ produced by bacteria and a calcium source (i.e., calcium hydroxide of the concrete matrix) must be available to trigger precipitation of $\mathrm{CaCO}_{3}$, and all these three mechanisms must happen simultaneously. It is likely that only at specific locations all these three conditions are respected, at which therefore precipitation of crystals is expected to be triggered. By self-healing the crack depth only partially as observed in the present study, some functional properties of concrete (i.e., compression strength) would obviously not be re-gained. However, the results of this study suggest that even a relatively thin (around $20 \mu \mathrm{m}$ ) layer of $\mathrm{CaCO}_{3}$ precipitated at the crack tip can help re-gaining water tightness in cracked concrete significantly. Re-gain of water tightness can theoretically improve the resistance to, for instance, corrosion of the embedded reinforcement. To clarify what are the implications that re-gain of water tightness of cracked specimens has on corrosion resistance of concrete, future tests will be conducted. Nevertheless, the proposed alkanoate-based healing agent showed promising results in terms of compatibility with the concrete environment and improved self-healing capacity.

\section{CONCLUSION}

From this study, the following major conclusions can be drawn:

The addition of PLA and AKD caused a decrease of heat released by the hydration of OPC. However, according to the compression strength and setting time tests, these inclusions did not mitigate the functional properties of mortar, therefore confirming good compatibility between the healing agents and the concrete environment; 
The Self-healing capacity of OPC mortar was significantly improved by the addition of PLA and AKD healing agents at both 28 days and 6 months as time of cracking. For specimens cracked at 28 days, the SHC of plain mortar was improved by 51.1 and $44.2 \%$ by the inclusion of PLA and AKD in the mortar matrix, respectively. For specimens cracked at 6 months age, the SHC of OPC mortar was overall improved by a factor of 4 and 6 thanks to the addition of PLA and AKD, respectively;

Through Optical microscope analysis, complete healing of the crack mouth of specimens cracked at both 28 days and 6 months age was visible upon the addition of PLA and AKD; Through ESEM analysis of the precipitates in the crack depth, significant formation of crystals could be observed for PLAand $\mathrm{AKD}$-containing specimens, while only thin layers of precipitates could be observed at the sides of the cracks for Ctrl specimens. For PLA- and AKD-specimens, precipitates could be observed at up to around $20 \mathrm{~mm}$ deep in the crack, regardless the age at which pre-cracking occurred.

Consumption of the proposed healing agent is further confirmed by non-invasive oxygen consumption test, according to which the alkanoates-based HA can be metabolized by bacteria in a concrete-simulated environment.

\section{REFERENCES}

De Belie, N., Gruyaert, E., Al-Tabbaa, A., Antonaci, P., Baera, C., Bajãre, D., et al. (2018). A review on self-healing concrete for damage management of structures. Materials Interface Sci. 5 (17), 1800074. doi:10.1002/admi.201800074

de Rooij, M., Van Tittelboom, K., De Belie, N., and Schlangen, E. (2013). Selfhealing phenomena in cement-based materials: state-of-the-art-report of RILEM Technical Committee 221-SHCRILEM state of the art report. Dordrecht, Netherlands: Springer, Vol. 11.

Edvardsen, C. (1999). Water permeability and autogenous healing of cracks in concrete. ACI Mater. J. 96 (4), 448-454. doi:10.1680/iicsdac.28241.0047

Ferrara, L., Van Mullem, T., Alonso, M. C., Antonaci, P., Borg, R. P., Cuenca, E., et al. (2018). Experimental characterization of the self-healing capacity of cement based materials and its effects on the material performance: a state of the art report by COST action SARCOS WG2. Construct. Build. Mater. 167, 115-142. doi:10.1016/j.conbuildmat.2018.01.143

Hearn, N. (1998). Self-sealing, autogenous healing and continued hydration: what is the difference? Mater. Struct. 31 (8), 563-567. doi:10.1007/ bf02481539

Jonkers, H. M., Thijssen, A., Muyzer, G., Copuroglu, O., and Schlangen, E. (2010). Application of bacteria as self-healing agent for the development of sustainable concrete. Ecol. Eng. 36, 230-235. doi:10.1016/j.ecoleng.2008.12.036

Kim, J. S., and Schlangen, E. (2011). "Self-healing in ECC stimulated by SAP under flexural cyclic load," in 3rd international conference on self- healing materials, Bath, United Kingdom, June 27-29, 2011 [abstract].

Lee, S. Y. (1996). Plastic bacteria? progress and prospects for polyhydroxyalkanoate production in bacteria. Trends Biotechnol. 14, 431-438. doi:10.1016/01677799(96)10061-5

Li, V. C., Lim, Y. M., and Chan, Y. W. (1998). Feasibility study of a passive smart self-healing cementitious composite. Compos. B. Eng. 29 (6), 819-827. doi:10. 1016/s1359-8368(98)00034-1

Li, V. C., and Yang, E. (2007). "Self-healing in concrete materials," in Self-healing materials-an alternative approach to 20 centuries of materials science. Editor S. van der Zwaag (Dordrecht, Netherlands: Springer), 161-194.

Luo, M., Qian, C. X., and Li, R. X. (2015). Factors affecting crack repairing capacity of bacteria-based self-healing concrete. Construct. Build. Mater. 87, 1-7. doi:10. 1016/j.conbuildmat.2015.03.117

\section{DATA AVAILABILITY STATEMENT}

The raw data supporting the conclusions of this article will be made available by the authors, without undue reservation.

\section{AUTHOR CONTRIBUTIONS}

ER and CV contributed equally to this work. Their contribution include the investigation, conceptualization, data analysis and writing the present original draft. RM contributed during the data analysis and the review and editing process. RK, OC, and $\mathrm{HJ}$ contributed through supervision and during the review and editing process.

\section{ACKNOWLEDGMENTS}

The authors would like to thank Arjan Thijssen for his assistance with the Environmental Scanning Electron Microscope analysis. Financial support from Netherlands Organization for Scientific Research NWO-TTW (grant ALWGK.2016.021) for this work is gratefully acknowledged.

Mors, R. M., and Jonkers, H. M. (2017a). Feasibility of lactate derivative based agent as additive for concrete for regain of crack water tightness by bacterial metabolism. Ind. Crop. Prod. 106, 97-104. doi:10.1016/j.indcrop.2016.10.037

Mors, R., and Jonkers, H. M. (2017b). Effect on concrete surface water absorption upon addition of lactate derived agent. Coatings 7, 51. doi:10.3390/ coatings7040051

Neville, A. (2002). Autogenous healing-a concrete miracle. Concr. Int. 24, 76-82.

Neville, A. M. (1995). Properties of concrete. London, United Kingdom: Longman, Vol. 4.

Palin, D., Jonkers, H. M., and Wiktor, V. (2016). Autogenous healing of sea-water exposed mortar: quantification through a simple and rapid permeability test. Cement Concr. Res. 84, 1-7. doi:10.1016/j.cemconres.2016.02.011

Palin, D., Wiktor, V., and Jonkers, H. M. (2017). A bacteria-based self-healing cementitious composite for application in low-temperature marine environments. Biomimetics 2 (3), 13. doi:10.3390/biomimetics2030013

Pungrasmi, W., Intarasoontron, J., Jongvivatsakul, P., and Likitlersuang, S. (2019). Evaluation of microencapsulation techniques for MICP bacterial spores applied in self-healing concrete. Sci. Rep. 9 (1), 12484-12510. doi:10.1038/s41598-019-49002-6

Rodríguez, C. R., de Mendonça Filho, F. F., Mercuri, L., Gan, Y., Rossi, E., Anglani, G., et al. (2020). Chemo-physico-mechanical properties of the interface zone between bacterial PLA self-healing capsules and cement paste. Cement Concr. Res. 138, 106228. doi:10.1016/j.cemconres.2020.106228

Schultz, R. J. (1987). A discussion of the paper "effect of lactic acid on the hydration of Portland cement". Cement Concr. Res. Editors N. B. Singh, S. Prapha Singh, and A. K. Singh, 17, 365-366. doi:10.1016/0008-8846(86)90092-X

Singh, N. B., Prabha, S., and Singh, A. K. (1986). Effect of lactic acid on the hydration of Portland cement. Cement Concr. Res. 16, 545-553. doi:10.1016/ 0008-8846(86)90092-x

Snoeck, D., Dewanckele, J., Cnudde, V., and De Belie, N. (2016). X-ray computed microtomography to study autogenous healing of cementitious materials promoted by superabsorbent polymers. Cement Concr. Compos. 65, 83-93. doi:10.1016/j.cemconcomp.2015.10.016

Taplin, J. H. (1960). “Chemistry of cement," in Proc. 4th international symposium chem. com., NBS monograph 43, Washington, DC, October 5-8, 1960, Vol. II, 927.

Tziviloglou, E., Wiktor, V., Jonkers, H. M., and Schlangen, E. (2016b). Bacteriabased self-healing concrete to increase liquid tightness of cracks. Construct. Build. Mater. 122, 118-125. doi:10.1016/j.conbuildmat.2016.06.080 
Tziviloglou, E., Wiktor, V., Jonkers, H. M., and Schlangen, E. (2016a). "Performance requirements to ensure the crack sealing performance of bacteria-based selfhealing concrete," in 9th international conference on fracture mechanics of concrete and concrete structures, Berkeley, CA, May 9, 2015.

Van Tittelboom, K., and De Belie, N. (2013). Self-healing in cementitious materials-a review. Materials 6, 2182-2217. doi:10.3390/ma6062182

Van Tittelboom, K., De Belie, N., Van Loo, D., and Jacobs, P. (2011). Self-healing efficiency of cementitious materials containing tubular capsules filled with healing agent. Cement Concr. Compos. 33 (4), 497-505. doi:10.1016/j.cemconcomp.2011.01.004

Vermeer, C. M., Rossi, E., Tamis, J., Jonkers, H. M., and Kleerebezem, R. (2021). From waste to self-healing concrete: a proof-of-concept of a new application for polyhydroxyalkanoate. Resour. Conserv. Recycl. 164, 105206. doi:10.1016/j. resconrec.2020.105206

Wang, J., Mignon, A., Trenson, G., Van Vlierberghe, S., Boon, N., and De Belie, N. (2018). A chitosan based $\mathrm{pH}$-responsive hydrogel for encapsulation of bacteria for self-sealing concrete. Cement Concr. Compos. 93, 309-322. doi:10.1016/j.cemconcomp.2018.08.007

Wang, J. Y., Soens, H., Verstraete, W., and De Belie, N. (2014a). Self-healing concrete by use of microencapsulated bacterial spores. Cement Concr. Res. 56, 139-152. doi:10.1016/j.cemconres.2013.11.009

Wang, J. Y., Snoeck, D., Van Vlierberghe, S., Verstraete, W., and De Belie, N. (2014b). Application of hydrogel encapsulated carbonate precipitating bacteria for approaching a realistic self-healing in concrete. Construct. Build. Mater. 68, 110-119. doi:10.1016/j.conbuildmat.2014.06.018
Wiktor, V., and Jonkers, H. M. (2011). Quantification of crack-healing in novel bacteria-based self-healing concrete. Cement Concr. Compos. 33 (7), 763-770. doi:10.1016/j.cemconcomp.2011.03.012

Xu, H., Lian, J., Gao, M., Fu, D., and Yan, Y. (2019). Self-healing concrete using rubber particles to immobilize bacterial spores. Materials 12 (14), 2313. doi:10. 3390/ma12142313

Yang, Y., Lepech, M. D., Yang, E.-H., and Li, V. C. (2009). Autogenous healing of engineered cementitious composites under wet-dry cycles. Cement Concr. Res. 39 (5), 382-390. doi:10.1016/j.cemconres.2009.01.013

Conflict of Interest: Author RM was employed by company Green-Basilisk B.V.

The remaining authors declare that the research was conducted in the absence of any commercial or financial relationships that could be construed as a potential conflict of interest.

Copyright (c) 2021 Rossi, Vermeer, Mors, Kleerebezem, Copuroglu and Jonkers. This is an open-access article distributed under the terms of the Creative Commons Attribution License (CC BY). The use, distribution or reproduction in other forums is permitted, provided the original author(s) and the copyright owner(s) are credited and that the original publication in this journal is cited, in accordance with accepted academic practice. No use, distribution or reproduction is permitted which does not comply with these terms. 